\title{
COST BENEFITS ANALYSIS OF PH.D EDUCATION IN NIGERIA
}

\author{
Adu, Ebenezer Taiwo ${ }^{1}{ }^{凶}$ and Ajayi, Oyedokun Samuel ${ }^{1}$ \\ ${ }^{1}$ Department of Multi-Disciplinary Studies, Bamidele Olumilua University of Education, Science and Technology, Ikere, \\ Ekiti, Nigeria
}

Received 26 May 2021

Revised 7 June 2021

Published 30 June 2021

Corresponding Author

Adu, Ebenezer Taiwo, aduebeneze

rtaiwo@gmail.com

DOI 10.29121/

granthaalayah.v9.i6.2021.3970

Funding: This research received no specific grant from any funding agency in the public, commercial, or not-for-profit sectors.

Copyright: (C) 2021 The Author(s). This is an open access article distributed under the terms of the Creative Commons Attribution License, which permits unrestricted use, distribution, and reproduction in any medium, provided the original author and source are credited.

\section{ABSTRACT}

This research work examined the cost benefits of $\mathrm{Ph}$. D programmes in Nigeria. It was a descriptive design of a survey type. The population of the study was all the lecturers and Ph.D students of the University of Ado-Ekiti, Nigeria, 150 Lecturers and students were selected through simple random sampling and purposive techniques. Two sets of research instruments were used one for the lecturers and the second one for the students currently undergoing Ph.D programmes. The validity of the instruments was done with the use of content, construct and face validities. Descriptive analysis was used to analyse the data collected. The results showed that the cost of Ph.D programme was higher compare to lower degrees, the prospect cadre for Ph.D was high and that the financial and other benefits of Ph.D holders were higher than other degrees.

Keywords: Cost, Benefit, Cost Benefit, Ph.D, University

\section{INTRODUCTION}

Economic analysis of education project, programmes and policies is based on the concept of welfare economic which is especially within economics that concentrates on the effects of different actions on overall and individual well being. In its ideal form, welfare economics maximizes aggregate utility available for a given set of input (Moffat 1978). Welfare economics is a collection of proposition and analytical devices useful for evaluating resource allocation decision. Welfare economics can be used to evaluate government programmes like education programmes. It is a scientific and political natural procedure that neither compromises with government nor opposes them (Greenwald, 1982).

Compared with other programmes, the cost of having $\mathrm{Ph}$. D certificate indicates the benefits to be derived from it. That is why Hollands et al. (2017) revealed that "- the programs may differ in length, frequency of intervention, duration of each session, number of students served over the year, materials, equipment, and facilities 
needed and the amount of teacher training required will affect the costs of implementation'. Hence, it will determine the utilitarian gains after obtaining the degree.

Lu, (2014) sees Ph.D. as an abbreviation for Doctor of Philosophy, which is a doctoral degree. Obtaining a Ph.D. degree means you have an exclusive specialty in your field. Ph.D. candidates are expected to engage in thought experiments, reason about problems, and solve problems in sophisticated ways. Students can apply for a Ph.D. program directly after completing a bachelor's degree, while some schools also require a Master's degree before entering a Ph.D. program. The exact number of years varies from four to eight years, which highly depends on the field, the student's research topic, and the student's skills. A Ph.D. degree also requires students to pass comprehensive exams and a large scholarly project called a dissertation.

Some people in the society believe that running a $\mathrm{Ph}$. D. programme is a risky investment and there are many other issues to consider apart from the increased chance of getting jobs. Their belief is that, investing on business is preferable to investing on $\mathrm{Ph}$. D programme. Untimely death of candidate even after completing the programme will make the investment a mere waste. Some claim that nothing to learn again after first or second degree compared with the experience gained on the job. However, many believe that higher education though risky, is still a very good investment. Having $\mathrm{Ph} \mathrm{D}$ is the greatest insurance for increasing job.

In recent time, it seems that the quest for Ph.D has been on the increase. One would wonder the reason for this high demand. Is it that the cost of running and obtaining the degree is lower compared to that of the lower degree? What actually motivates many people into the Ph.D programme? The University of Ibadan now allocates $60 \%$ for post graduate programme and $40 \%$ for under graduate programmes. This could be seen as a positive response to the high demand for Ph.D degree programmes.

There are five steps involved in the performance of a cost benefit analysis. First, all effects of the project are identified. Typically, such effects might include changes in flexibility efficiency, equity employability, level of satisfaction of social demand, output level, prices, income distribution, environmental and social parameters. The effects are identified both for the present and for all relevant future time period. This may involve forecasting trend and event about which little may be known with certainty. This key in this step is estimating as accurately as possible what difference the project will have as show in Table 1 below:

\begin{tabular}{|c|c|c|c|c|c|c|c|c|}
\hline \multirow[t]{2}{*}{$\begin{array}{l}\text { Effect of } \\
\text { project on }\end{array}$} & \multicolumn{2}{|c|}{$\begin{array}{c}\text { Efficiency } \\
\text { (output) }\end{array}$} & \multicolumn{2}{|c|}{$\begin{array}{c}\text { Equality (distribution } \\
\text { of income) }\end{array}$} & \multicolumn{2}{|c|}{$\begin{array}{c}\text { Employability } \\
\text { (earning) }\end{array}$} & \multicolumn{2}{|c|}{ Social demand } \\
\hline & + ve & -ve & + ve & -ve & +ve & -ve & +ve & -ve \\
\hline Present & & $*$ & & $*$ & $*$ & & & $*$ \\
\hline Future & $*$ & & $*$ & & $*$ & & $*$ & \\
\hline
\end{tabular}


Table 1 shows the process of identifying various effects of a project. Analyst should estimate what differences the project will make (in term of change in output, price, income, social parameters, etc) both now and in future.

There is need to identify and measure cost of a project in order to make a comparison of the cost and benefits. Unrealistic estimate may be major cost of a profitable or a desirable project on paper turning into an unprofitable or inefficient estimate may affect the programme. Also, the extent that financial provisions are guided by cost estimate may affect the change of project completion. This is particularly so if such cost estimate is unrealistic.

Costs of education programmes are whatever we give in order to execute the project. These costs can be broken down into direct and indirect. The direct cost falls into three categories; namely construction, operation and maintenance of an educational project. On the other hand, the indirect or the implicit cost represents the value of forgone opportunities, but do not involve actual cash payment.

In educational industry, the costs of education may be viewed from two different angles: the cost of production, that is, the cost involved in operation of education by the relevant education authorities, and the cost of education to the students (and their parents) in form of the fees and other educational expenditures in Nigeria. The costs of education are shared by the students and the school authorities and the ministry of education. In general, the cost benefit approach looks at education as an investment for the whole community measured by mean of social rates of return. Also, education is an investment for the individual by using the private rates of return. By choosing to go to school, the individual incurs certain direct and indirect cost such as tuition, earning foregone and other fees.

Benefits are economic and non-economic returns to education. Wood hall (1977) remarks that products of education are for the benefits of both educated individuals and the community as a whole. T. Adeyemi (2007) supported Woodhall (1977) that these benefits consist of both economy and non-economy and both consist of consumption benefits which contribute to parents' welfare and investment benefit which contributes to future welfare. T. Adeyemi (2007) therefore reported that since higher education entails direct economic benefit for individuals in form of occupation choice, higher incomes, lower risk of unemployment and increased investment. Hence, individual should be expected to finance education himself.

Investment is the undertaking of any commitment which involves an initial sacrifice, followed by subsequent benefits. Education as an investment therefore, means that by spending our saving in purchasing or providing education guaranteed for a long period of time. The saying that if education is costly one should try ignorance may not be applicable to Ph.D programme. This is because candidates must have been in possession of Masters' Degree but believes that there is need to take out consumption purse (that is money available for satisfying immediate wants) and divert it to investment fund. Sofiane (2017) proved that cost benefit of any educational programme is important in which after computing the individual and the social 
cost of the graduate students, it is necessary to estimate both the individual returns expected to be collected, as well as the social returns received by the community from the higher education. It is observed that the benefit from education consists of an increase in the productivity of educated person in any non-monitory satisfaction he may get from the particular education and in any spill over effects which education may have on the rest of the community. Akangbu (1981) referred to it as indirect benefits of education which may be difficult to satisfy but analysis can be made of the age earnings profile of the Ph.D holders and comparing it with the profile of the workers with lower certificates.

Akangbu (1981) and T. Adeyemi (2007) argued that information on earning of educated individuals are virtually absent in some countries with the U S A being the possible exception. The benefits derived from education go beyond earnings. The benefits that one can derive are the one which can be calculated or quantified. These 'are tangible and intangible benefits. That is those values which are not usually measured by market price e.g., aesthetics, culture, environmental, the value of life, the value of order and security.

The researchers therefore observed that the cost benefits of $\mathrm{Ph}$. D programme were higher than other degrees (lower degrees). The benefits and cost of Ph.D may not be necessarily measured at market prices. To become a lecturer, you will need to have the relevant degree for the subject you may wish to teach. You will need to have a good bachelor's degree (not less that second class) with master degree. However, a Ph. D. is the main qualification one needs to achieve to become a full-time lecturer. It depends entirely upon the University's requirements. As a general rule, they want someone to have a PhD. In addition, less research focused universities are more likely to be willing to permit someone with a second-degree certificate holder to teach, particularly at undergraduate level.

The value of cost that the society places on Ph. D programme increase the benefits derived from the degree. The value attached to $\mathrm{Ph}$. D degree is observed to have increased the rate of expenditure. Adeyemi (2005) argued that the rate of expenditure is determined by the net benefits derived from such programme. The value attached to the certificate motivates individual to get themselves involved in the programme no matter the challenges on the way. The cost of Ph.D financially, morally and socially is viewed to be greater than first degree or second degree programme as a result of benefits derived after obtaining the degree.

It is observed that when the cost is greater than the benefit one will not want to invest his resources on such project since it will be a labour loss. "National Teachers' Institute" (2008) revealed that when the cost is less than the benefit, one will invest resources in it since one will make profit. However, when the cost equals to benefit, then one will have to consider some other factors such as whether one wants to embark on the project so as to gain some popularities, or not. After considering such factors, there is the need to decide on what to do, Muzaze (1985) earlier proved that there is a direct link between earnings and productivity, that is to say, that the higher 
the pay the higher the productivity Adu (2002) . It is very difficult to establish this in a developing country like Nigeria in which the higher the pay may be the less the worker level of productivity but what is observed to be certain is the fact that the higher the certificate, the higher the employment opportunity. Hence, there will be higher financial gain.

\subsection{STATEMENT OF THE PROBLEM}

It is observed that due to job insecurity, many people on the job believe they need to seek for higher certificates. In order to get to the peak of the ladder, some believe that higher certificates must be possessed. This is observed to have led to higher number of workers seeking for higher certificate even more than required. The importance attached to postgraduate degree certificates in academic, seems to have led to an increase demand for Ph D programmes. In academics setting, a Master's Degree certificate holder cannot reach the peak of his carrier without having $\mathrm{Ph} \mathrm{D}$ certificate. This is observed to have called for an increase in demand for Ph.D certificate. The problem of this study therefore was to determine cost benefits of Ph.D programme to the individual and society in general. In examining the problem, some research questions were raised.

\subsection{PURPOSE OF THE STUDY}

Investing in education seems to be discouraging in the contemporary Nigerian societies. Those who obtained degree certificates seem to have made efforts in futility as a result of those with the certificate who are in the labour market. Many who have higher degree certificates are roaming in the streets looking for job opportunities. Due to the growing doubts about the feasibility of investment on higher education, this research work examined the cost benefit of Ph. D in Nigeria.

\subsection{RESEARCH QUESTIONS}

1. What does it cost an individual to run a Ph.D programme compared to Master Degree programme in Nigerian University?

2. What are terminal cadre prospects differential to lecturers with M.ed and Ph.D degrees in academic community?

3. Is there any economic benefit for Ph.D holders over master degree in Nigeria?

\section{METHODOLOGY}

The design of this study is a descriptive survey type. Oppenheim (1966) defines a survey as a form of planned collection of data for the purpose of analyzing the relationship between variables. The population comprised of the academic staff and doctoral students of government owned Universities in Nigeria. Five Universities were sampled. In theses sampled universities, 150 academic staff and 150 doctoral students 
in this state-owned university were selected.

Two sets of instruments were used. The first was a questionnaire titled 'Private cost of Ph.D programme' were administered to doctoral students which consisted of institution, sex, faculty, department, employment status, tuition cost, qualifications, employer, past occupation working and basic salary, average tax paid and allowances. The second instrument was a checklist which was used to seek information on various academic career positions available in the Universities in Nigeria. Face, content and construct validity were ensured though experts in Text and Measurement.

The reliability of the questionnaire was carried out by administering the instrument on 25 participants in one of the schools outside the sampled area using testretest method. They were of comparable age with the participants in this study. After a period of two weeks, the instrument was re -administered on the same participants. The data collected were collated and analyzed using the Pearson's Product Moment Correlation Analysis, which yielded reliability co-efficient of 0.89 . This value was considered high enough to make the instrument reliable for use in this study. However, based on the nature of the second instrument (checklist), Cronbach's Alpha was used.

The research instruments were administered by the researchers and the data analyses using descriptive analyses such as frequency counts, mean and percentages).

\section{RESULTS AND DISCUSSIONS}

\subsection{DATA ANALYSIS}

Research Question 1: what does it cost an individual to run a Ph.D programme compared to other degree programme in Nigeria University?

In analyzing this, the costs were compared to identify whether the cost of Ph.D was higher using percentages as in Table 2 below:

Table 2 Private cost of Ph. d programme compared to the cost of M.Ed programme in Nigeria University.

\begin{tabular}{llllllll}
\hline S/N & ITEMS & MASTER DEGREE & $\mathbf{\%}$ & Ph. D Degree & $\mathbf{\%}$ & Total & $\boldsymbol{\&}$ \\
1 & School fees & 150,000 & 30 & 350,000 & 80 & 500,000 & 100 \\
\hline 2 & Text books & 28,000 & 41.18 & 40,000 & 58.82 & 68,000 & 100 \\
3 & Registration fees & 10,000 & 40.00 & 15,000 & 60.00 & 25,000 & 100 \\
\hline 4 & PG Reg. Fees & 3,000 & 37.50 & 5,000 & 62.50 & 8,000 & 100 \\
\hline 5 & Transportation & 50,000 & 56.04 & 8,000 & 43.96 & 91,500 & 100 \\
\hline 6 & Research cost & 51,000 & 53.13 & 45,000 & 46.87 & 96,000 & 100 \\
7 & Internet cost & 60,000 & 60 & 60,000 & 50.00 & 120,000 & 100 \\
\hline 8 & Cost of thesis & 210,000 & 41.18 & 300,000 & 58.82 & 500,000 & 100 \\
\hline
\end{tabular}

Note that items 1 to 7 are multiplied by the no of years for obtaining the degree. Only Serial No.8 is constant. 
From the above table, it was discovered that the cost of Ph. D was greater than that of Master and degree programmes. In the Universities sampled, it was discovered that the tuition fees for both degrees were not the same, the average school fees was \# 150,000 for master degree while that of Ph. D was \#350,000.00 representing $80 \%$ of the costs for the two programmes. All items 1-7 are multiplied by the number of years spent for the programmes. The cost of producing theses for both $\mathrm{Ph} \mathrm{D}$ and Master programmes is fixed depending on the market price. The cost of producing master's thesis is \#210,000.00 (41.18\%) while that of $\mathrm{Ph} \mathrm{D}$ dissertation is \#300,000.00 representing 58.83\%. therefore, it the cost of obtaining Ph.D certificate was higher than cost of obtaining master's degree certificate.

Research Question 3: What are the terminal cadre prospect differentials for lecturers with M. Ed and Ph. D degrees in Universities in Nigeria?

To measure terminal cadre prospect for the workers of these degree certificate in differential, the minimum and maximum ranks are identified with financial implications. This is indicated in the Table 3 below.

\begin{tabular}{ccccccccc}
\hline Table 3 & Terminal cadre prospect differential for M. Ed and Ph. D degree. & \\
\hline Cadre & Ph.D & $\begin{array}{c}\text { Salary Total } \\
\left(\mathbf{X}^{1}\right) \#\end{array}$ & $\mathbf{\%}$ & $\begin{array}{c}\left(\mathbf{X}^{1}\right) \\
+\left(\mathbf{X}^{2}\right)\end{array}$ & $\mathbf{\%}$ & $\begin{array}{c}\text { Master } \\
\text { degree }\end{array}$ & $\begin{array}{c}\text { Salary } \\
\left.\text { Total } \mathbf{X}^{2}\right)\end{array}$ & $\%$ \\
$\begin{array}{c}\text { Minimum } \\
\text { Cadre }\end{array}$ & $\begin{array}{c}\text { Lec- } \\
\text { turer } \\
\text { II }\end{array}$ & 137,459 & 52.13 & 170,386 & 100 & $\begin{array}{c}\text { Asst } \\
\text { lecturer }\end{array}$ & 89,562 & 47.86 \\
$\begin{array}{c}\text { Maximum } \\
\text { cadre }\end{array}$ & $\begin{array}{c}\text { Profes- } \\
\text { sor }\end{array}$ & 501,689 & 74.19 & 47,657 & 100 & Lecturer I & 223,292 & 25.81 \\
\hline
\end{tabular}

From the above table, it was discovered that minimum cadre for Ph.D was Lecturer II with \#137,459,000 as salary and Assistant Lecturer for Masters degree holder with salary of \#89,564. This shows that Ph.D. degree programme has higher cost benefits than Master degree programme.

Research Question 3: Is there any career prospect for holder of Ph. D certificate over master degree certificate holder?

In answering this question, the maximum career prospects of both certificates' holders are identified. The various academic career positions that are available in the universities were identified using checklist. The results are as presented in Table 4

Table 4 Career prospects between $\mathrm{Ph}$. D and master degree holders.

\begin{tabular}{ccccccc}
\hline Degree & $\begin{array}{c}\text { Vice Chancel- } \\
\text { lorship }\end{array}$ & Professorsh & Directors & Deanship & $\begin{array}{c}\text { Headship of } \\
\text { Department }\end{array}$ & Teaching \\
Ph.D & $\sqrt{ }$ & $\sqrt{ }$ & $\sqrt{ }$ & $\sqrt{ }$ & $\sqrt{ }$ & Full \\
Master & & & & & $\sqrt{ }$ & $\sqrt{ }$ \\
\hline
\end{tabular}


From above table, it shows that there was higher Career prospects for Ph.D certificate holder over Masters' certificate holder. A Ph. D holder can get to the peak of his career as a professor master certificate holder has limited cadre prospect of Lecturer 1 which can only assist in teaching and research work. This research therefore revealed that only $\mathrm{Ph} \mathrm{D}$ degree holders are regarded as full lecturers in the Nigerian Universities.

\subsection{DISCUSSIONS}

The finding of the study revealed that the cost of Ph.D was higher compared to that of Master degree. This might be as a result of the utilitarian value attached to the Ph.D programme. This is observed to be the major reason why most candidates failed to continue the programme. The cost per student for Ph.D programme was about $50 \%$ greater than the Masters degree programme and about 25 times greater than that of bachelor degree programme. This seems to have led to withdrawal of many candidates after completion of course work. These finding agreed with T. Adeyemi (2007) view that the benefits which one can derive are the one which when calculated benefits either tangible will motivate consumer but the marginal benefit which is the slightest always increase as a result of any slightest change in the factor of production. These factors can be lack of capital or time.

The study also revealed that the Ph.D had a greater career prospect of getting to the peak of academic ladder compared to other degree. This is in line with the Biblical statement that to whom much is given, much is expected. The maximum cadre of master degree is lecturer I while that of Ph.D is Professor. The latter cadre is attached with many opportunities because the higher the quality the more efficiency it will be.

The result of research question indicated that the prospect of financial benefit of Ph. D was higher than that of other degrees. This is in line with Adesina (1981) that the rate of return or cost benefit analysis primarily views education as an investment in human resource development, therefore, added academic qualifications are expected to open door to more opportunities. As a result of cost-effectiveness, the society attaches importance to the Ph.D certificate compared to other degree as a result of the cost effectiveness that lead to cost benefits.

\section{CONCLUSION}

Based on the results, it is concluded that the cost of $\mathrm{Ph} . \mathrm{D}$ degree programme is higher compared to other degrees in Nigerian Universities. Also the higher opportunities for $\mathrm{Ph} . \mathrm{D}$ holders to reach the peak of academic cadre and other financial benefits of Ph.D holders were far above Master degree holders which is the nearest certificate to it.

\section{RECOMMENDATIONS}

Based on the findings of this research, the following recommendations are made: 
1. Government should come to the aid of doctoral degree students by giving scholarship to them.

2. More opportunities should be given to Ph.D holders so that the academic exposure will be of great use in education communities.

3. Tuition and other sundry fees of doctoral degree programmes should be downward reviewed.

\section{REFERENCES}

Adesina, S. (1981). Introduction To Education Planning Ile-Ife. University Of If E Press.

Adeyemi, T. (2007). Economics Of Education. Ado-Ekiti. Green Line Publication.

Adeyemi, T. O. (2006). Fundamentals Of Educational Management. Lagos. Atlantic Associated Publishers.

Adu, E. T. (2002). Relationship Between Job Satisfaction And Job Performance Of Academic Staff Of Federal University Of Technology, Akure University Of Ado-Ekiti.

Akangbu, S. (1981). The Economics Of Educational Planning In Nigeria.Unpublished Course Material.

Borode, M., \& Unpublished Ph.D Thesis. (1997). Comparative Cost-Benefit Analysis Of Bachelor Of Education Sandwich And Conventional Degree Programme In Ondo State.

Hollands, F. M., Levin, H. M., \& Department Of Education, Institute Of Education Sciences, National Center For Education Evaluation And Regional Assistance, Analytic Technical Assistance And Development. (2017). The Critical Importance Of Costs For Education Decisions., 2017-274. Retrieved from Http://Ies.Ed.Gov/Ncee/Edlabs

Muzasi, J. C. S. (1982). The Theory And Practicse Of Educational Administration.

National Teachers' Institute. (2008). In Introduction To Educational Management And Planning. Kaduna: DLS.

Oppenheim, A. N. (1966). Questionnaire Deesign And Attitude Measurement London.

Sofiane, B. H. M. (Ed.). (2017). Investment Evaluation Of Higher Education Through CostBenefit Analysis: Evidence From Adrar University-Algeria. Journal of Education And Practice, 8(3), 86-96.

Woodhall, \& Blang, M. (1965). Productivity Trends In British University Education 1938-62., 4883-498. 